\title{
Digital Payments Adoption Research: A Review of Factors Influencing Consumer's Attitude, Intention and Usage
}

\author{
Pushp P Patil ${ }^{1}$, Nripendra P. Rana ${ }^{2}$, Yogesh K. Dwivedi ${ }^{3}$ \\ ${ }^{1}$ Emerging Markets Research Centre (EMaRC), School of Management, Swansea University Bay Campus, Swansea, SA1 \\ $8 \mathrm{EN}, \mathrm{UK}$ \\ \{919286@swansea.ac.uk; pushpppatil@gmail.com\} \\ ${ }^{2}$ Emerging Markets Research Centre (EMaRC), School of Management, Swansea University Bay Campus, Swansea, SA1 \\ $8 \mathrm{EN}, \mathrm{UK}$ \\ \{n.p.rana@swansea.ac.uk\} \\ ${ }^{3}$ Emerging Markets Research Centre (EMaRC), School of Management, Swansea University Bay Campus, Swansea, SA1 \\ $8 \mathrm{EN}, \mathrm{UK}$ \\ \{y.k.dwivedi@Swansea.ac.uk\}
}

\begin{abstract}
Digital payment methods (DPMs) are evolving fast but they are yet to be widely adopted particularly in the developing countries. An initial review of literature suggests that several studies have already been conducted on this topic for understanding antecedents of digital payments adoption. However, only a few studies have examined this emerging topic in the context of developing countries. The aim of this submission is to identify antecedents of consumer adoption and usage of digital payments methods. The results of this literature analysis suggest that constructs related to technology acceptance model (TAM) and unified theory of acceptance and use of technology (UTAUT) along with trust and risk are the most frequently examined constructs for determining consumer's behavioural intention to use and usage of DPMs. The findings from this work can help researchers selecting factors for inclusion in the future empirical works on this topic.
\end{abstract}

Keywords: Adoption, Cashless Payments, Construct Mapping, Digital Payments, Metaanalysis, Mobile Payments

\section{Introduction}

The adoption and use of emerging digital devices and applications (i.e. mobile and other handheld devices, Near Field Communication (NFC), mobile wallets, P2P apps, quick response code and wearable) complemented with Internet connectivity are gradually shifting various activities from the real world to a virtual world (De Kerviler et al., 2016). Consumers are also moving towards changing their payment method from cash and cheque based system to contactless devices (Patil et al., 2017).

Despite several benefits (including potential to bring financial inclusion by offering financial services to the unbanked masses and improve their lives for better, enhancing transparency in financial transactions, reducing tax envision and improving public welfare and delivery systems) of digital payment methods (DPMs) to various stakeholders including consumers, DPMs such as mobile payments have not yet widely adopted as expected in both developed and developing countries except for few countries such as Kenya and Philippines where mobile payments are readily accepted due to relative lack of penetration of formal banking system (Augsburg \& Hedman, 2014; Patil et al. 2017; World Economic Forum 2011). 
The slow adoption of DPMs by consumers provides motivation and relevance to undertake research in this area. However, several studies have already been conducted to examine factors influencing mobile payments adoption largely in the context of developed countries and there are some in developing countries context (Patil et al. 2017). Patil et al.'s (2017) study presented an initial review and attempted to identify limitations of existing work and research gaps that need further attention by researchers in this area. This review also identified dominant theories and models utilised in this domain (Patil et al. 2017). However, this review didn't present a detailed analysis of antecedents of consumer's attitude, intention, usage, satisfaction and continuance intention. Such review and analysis would help to unearth inconsistencies in existing research as well as help to discover well tried and tested antecedents for examining adoption and usage of digital payment methods. The aim of this study is, therefore, to undertake review and analysis of factors/constructs employed by existing studies on consumer adoption of digital payments methods.

The remaining sections of this article is structured as follows: Section 2 describes literature search and analysis method. The results are then presented in Section 3. Finally, Section 4 presents a brief concluding discussion and future research directions.

\section{Literature Search and Analysis Method}

As this work is focussed on analysing findings reported in existing studies, first step for this study was to identify relevant work published on digital payment methods/systems adoption. A keyword based search was considered appropriate in order to identify studies relevant to digital payment methods, which was achieved by utilizing the following keywords in the Scopus database: "Digital Payment" OR "Cashless Payment" OR "Mobile Payment" AND "Adoption" OR "Acceptance" OR "Diffusion" OR "Usage" OR "Intention" OR "Success" OR "Satisfaction". This search resulted in 109 studies, but after initial screening it was found that some studies were not relevant to consumer adoption to digital payments, which reduced total number of studies to 80 . However, some of these 80 articles (mainly conference papers) were not accessible through researcher's library, hence total number further reduced to 75 studies. The articles were deemed appropriate for inclusion in this study if the data collection of research took place among consumers or the studies developed conceptual model to be empirically tested on consumers at later stage.

Construct mapping was conducted to identify various independent variables (IVs) employed to determine influence of different dependent variables (DVs) such as behavioural intention (BI), usage (U), satisfaction and continuance intention. This was achieved by collecting the information regarding name of IVs and DV along with types of relationships (significant, insignificant or conceptual) reported between them, which we utilised to conduct analysis and mapping of constructs examined in existing works.

A detailed screening of search outputs suggests that existing studies have mainly examined issues related to mobile payments, Mobile Payment Devices (Smartphones), NFC, Contactless Mobile Payments and QR Mobile Payment System. This suggests that other forms of digital payments yet to be examined. Hence, the term digital payments in this paper 
is largely represent mobile payments and may have less relevance for any other form of digital payments.

\section{Results}

Constructs analysis undertaken in this study suggests that many constructs/factors/IVs have been utilised to determine different DVs (including attitude, behavioural intention (BI), adoption, usage and satisfaction) of digital payment methods. The IVs employed in existing studies belong to several dominant adoption and diffusion theories and models including Technology Acceptance Model (TAM), Innovation Diffusion Theory (IDT), Unified Theory of Acceptance and Use of Technology (UTAUT) and extended UTAUT (UTAUT2). The review presented below demonstrates that the main focus of existing empirical studies was on examining consumers' intention to adopt/use digital payment methods and very few attempted to explain usage behaviour and satisfaction.

\subsection{Antecedents of Consumer Attitudes towards Adoption of Digital Payment Methods}

A total of six studies have examined the role of different IVs on consumer attitude towards digital payment methods. These IVs include: Compatibility (Liebana-cabanillas 2015; Tian and Dong, 2013), Confidence and Facility of Use (Liebana-cabanillas et al. 2015a), Individual Mobility (Liebana-cabanillas 2015; Schierz et al. 2010), Perceived Ease of Use (Hossain \& Mahmud 2016; Liebana-cabanillas et al. 2015a; Schierz et al. 2010), Perceived Security (Liebana-cabanillas 2015; Schierz et al. 2010), Perceived Usefulness (Hossain \& Mahmud 2016; Liebana-cabanillas 2015; Schierz et al. 2010; Tian and Dong, 2013), Personal Innovativeness (Tian and Dong, 2013) and Subjective Norm (Liebana-cabanillas 2015; Schierz et al. 2010).

\subsection{Antecedents of Behavioural Intention}

PU from TAM was utilised by 22 studies to determine BI, which included 20 studies with significant effect (Andreev et al. 2012; Chandrasekhar \& Nandagopal 2016; Kim et al. 2016; $\mathrm{Wu}$ et. al. 2016; Zhong et al. 2013) and two studies with non-significant effect (Phonthanukitithaworn et. al. 2015; Li et al. 2014). The role of other constructs similar to PU from alternative theories have also examined. For example, Performance Expectancy (PE) from UTAUT examined by eight studies (Alshare \& Mousa, 2014; Morosan \& DeFranco, 2016; Slade et al., 2015a; Slade et al., 2015b) and Relative Advantage from IDT by three studies (Lu et al. 2011; Yang et al. 2012). This suggests that usefulness of digital payment methods for consumers plays a vital role in influencing their BI to adopt such emerging applications. The role of the PEOU has also been tested on BI by 15 studies, which include 11 studies with significant effects (Andreev et al. 2012; Di Pietro 2015; Kim et al. 2016; Zhong et al. 2013) and four studies with non-significant effects (Koenig-Lewis et al. 2015; Liu 2012; Phonthanukitithaworn et. al. 2015; Shin and Lee 2014). A total of six studies examined the role of Effort Expectancy (EE) (similar to PEOU), but only one study (Alshare \& Mousa 2014) reported significant effect on BI and remaining five studies (DeFranco 2016; Qasim and Abu-Shanab 2016; Slade et al. 2015ab) found non-significant effect. 
The remaining two IVs (i.e. Social Influence (SI) and Facilitating Conditions (FC)) from UTAUT are tested by relatively fewer number of studies. Only 10 studies examined role of SI on BI, which includes nine with significant effect (lshare \& Mousa 2014; Musa et al. 2015; Qasim \& Abu-Shanab 2016; Slade et al. 2015ab; Yang et al (2012) and remaining one study (Koenig-Lewis et al. 2015) reported non-significant result for this. Only three studies examined role of FC on BI with only one study reporting significant (Morosan \& DeFranco, 2016) and remaining three (Oliveira et al. 2016; Slade et al. 2015a) with non-significant results.

The role of additional constructs (namely, habit, price value (PV) and hedonic motivation (HM)) from the UTAUT2 are also less often tested. Three studies reported significant (Morosan \& DeFranco 2016; Slade et al. 2015a; Zhong et al. 2013) and one non-significant (Jia and Hull 2014) effects of Habit on BI. PV examined by only two studies (Oliveira et al. 2016; Slade et al. 2015a) and both reported non-significant influence on BI. HM or perceived enjoyment has been examined by four studies with two (Koenig-Lewis et al. 2015; Morosan \& DeFranco 2016) reporting significant and other two (Slade et al. 2015a; Oliveira et al. 2016) with non-significant effects on BI. The role of attitude has also been tested by five studies (Hossain \& Mahmud, 2016; Liebana-cabanillas, 2015; Liebana-cabanillas et al. 2015a; Schierz et. al 2010; Tian and Dong 2013), all with significant effect on BI. Five studies (e.g. Lu et al. 2011; Phonthanukitithaworn et al., 2015; Zhou 2011) have examined and reported significant effect of Cost/Perceived Cost on BI but only one such study (Yang et al., 2012) has reported non-significant effect of this construct.

Trust, risk and innovativeness have also been examined by digital payment adoption studies for determining their influence on BI. The role of Trust has been examined by 10 studies and majority (i.e. nine) of them (for example, Phonthanukitithaworn et al. 2015; Slade et al. 2015a; Xin et al. 2013; 2015; Qasim and Abu-Shanab 2016; Yan and Yang 2014) have reported its significant influence on BI. In contrast, Slade et al. (2015b) have found nonsignificant influence of trust on BI. 18 studies have tested the effect of Risk on BI, which include 15 studies (e.g. Andreev et al. 2012; Koenig-Lewis et al. 2015; Liebana-cabanillas et al. 2015a; Li et al. 2014; Lu et al. 2011; Oliveira et al. 2016; Slade et al. 2015ab) with significant influence and in the remaining three (Huang \& Liv 2012; Makki et al. 2016; Phonthanukitithaworn et al. 2015) with non-significant effect of this construct. Only seven studies examined the role of innovativeness and they all (Liebana-cabanillas 2015; Makki et al. 2016; Oliveira et al. 2016; Sam et al. 2014; Slade et al. 2015b; Thakur \& Srivastava 2014; Yang et al. 2012) have its significant influence on BI.

Other IVs that have been utilised to explain BI include information security (Alshare \& Mousa 2014; Di Pietro 2015; Oliveira et al. 2016; Zhong et al. 2013), privacy concerns (Morosan \& DeFranco 2016), knowledge (Koenig-Lewis et al. 2015), positive emotions (Wu et. al 2016), self-efficacy (Makki et al. 2016), subjective rules (Liebana-cabanillas et al. 2015a), network externalities (Qasim and Abu-Shanab 2016) and adoption reediness (Thakur \& Srivastava 2014). 


\subsection{Antecedents of Use/Usage Behaviour}

This literature review suggests that only four studies (Berrado et al. 2013; De Kervilar et al 2016; Hongxia et. al 2011; Koenig-Lewis et al. 2015; Tian \& Dong 2013) have examined usage behaviour of digital payment methods. These four studies examined role of several IVs such as risk (Berrado et al. 2013; De Kervilar et al 2016; Hongxia et. al 2011), BI (Hongxia et. al 2011; Koenig-Lewis et al. 2015; Tian \& Dong 2013), PEOU (Berrado et al. 2013), PU (Berrado et al. 2013; Tian \& Dong 2013), fee/cost (Berrado et al. 2013; Tian \& Dong 2013), and knowledge (Koenig-Lewis et al. 2015) for significantly influencing usage or actual behaviour of using digital payment methods.

\subsection{Antecedents of Satisfaction}

Only two studies (Lu et al. 2017; Zhou 2013) have tested the role of some antecedents for explaining satisfaction gained from using digital payment methods. Zhou's (2013) study suggests that flow, system and service quality has a significant effect on determining satisfaction from using mobile payment systems, where information quality had insignificant effect. Lu et al. (2017) examined the effects of post usages privacy protection perception, post usages social influence and post usages perceived mobility on satisfaction. The results from this study suggest that amongst three IVs only post usages perceived mobility significantly explained satisfaction (lu et al. 2017). However, none of the existing work has examined effects of actual or self-reported usage on satisfaction, which is an important consideration.

\subsection{Antecedents of Continuance Intention}

Like satisfaction, only two studies (Zhou 2013; 2014) examined antecedents of continuance intention. Zhou (2013) examined the role of flow, satisfaction and trust and found that all three constructs had a significant influence on continuance intention. Zhou's (2014) study suggests that flow, performance expectancy and trust had a significant influence on continuance intention.

\section{Concluding Discussion and Future Research Directions}

This study conducted a review of digital payments antecedents used to explain consumer attitude, intention, usage and satisfaction. The following salient points emerged from this literature analysis:

- Several studies have examined behavioural intention of consumers to adopt DPMs but very few studies attempted to examine usage. In early stages of digital payments adopters were very few so it was appropriate to focus on determining intention than actual usage behaviour. However, penetration and adoption of digital payments are now increasing so it is important to focus on usage/use behaviour.

- Theories and models, which are only partially utilised, suggest that theory testing and extension is weak in this emerging area of study. For example, not all constructs from UTAUT or UTAUT2 have been utilised. Mainly PE and EE have been tested followed by 
SI and very few studies tested the role of FC. For adequate contribution to theory as much as possible, all elements of a theory should be included in the empirical work.

- TAM is tested by several studies. This is a parsimonious model and good for applying in organisational settings but less suitable for examining complex domain such as consumer adoption of DPMs, where issue is not just limited to usefulness and ease of use but there are also other concerns such as trust, security, privacy, risks, anxiety and self-efficacy. Therefore, it is important to apply a more comprehensive theory in this domain.

- Attitude has been examined by a number of studies and found significant, which means it is a relevant construct but guiding theories such as TAM, UTAUT, UTAUT2 don't have this construct. However, a recent modification of UTAUT (see Dwivedi et al. 2017) has demonstrated that attitude plays a central in UTAUT model. Future studies recommended to adopt a simpler yet comprehensive UTAUT (Dwivedi et al. 2017) or other such alternative for guiding model for their empirical work.

- It is also important that future studies should also consider examining satisfaction and continuance intention as these aspects have not been examined yet, but they are vital for growth and sustainability of digital payments ecosystem.

- Existing studies have mainly examined mobile payment methods. Future studies should also focus on examining other forms of digital payment methods for a holistic development of digital payments ecosystems and emerging FinTech applications.

This review was based on literature search using only Scopus database, so studies that are not indexed in this database may have been excluded. Future literature reviews should consider other databases to address the limitations of this study. This study has provided only descriptive review of factors. Future studies should consider undertaking meta-analysis of existing results for estimating cumulative effect size to overcome problem of inconsistences and errors, which can help to formulate robust conclusions about influence of different factors.

\section{References}

Alshare, K., \& Mousa, A. (2014). The moderating effect of espoused cultural dimensions on consumer's intention to use mobile payment devices. In Proceedings of the 35th International Conference on Information Systems (pp.1-15).

Andreev, P., Pliskin, N., Rafaeli, S.: Drivers and Inhibitors of Mobile-Payment Adoption by Smartphone Users. International Journal of E-Business Research. 8, 50--67 (2012)

Andreev, P., Pliskin, N., \& Rafaeli, S. (2012). Drivers and inhibitors of mobile-payment adoption by smartphone users. International Journal of E-Business Research, 8(3), 50-67.

Augsburg, C., \& Hedman, J. (2014). Value added services and adoption of mobile payments. Proceedings of the 16th International Conference on Electronic Commerce (August 5-6, 2014), Philadelphia: ICEC.

Barn, S.: The mobile commerce value chain: analysis and future developments. International Journal of Information Management. 22(2), 91--108 (2002)Beng, T. C., \& Eze, U. C. (2010). Determinants of Mobile Payment Usage in Malaysia: A Conceptual Perspective. Journal of Electronic Banking Systems, 2010, a1-9.

Berrado, A., Elfahli, S., El Garah, W.: Using data mining techniques to investigate the factors influencing mobile payment adoption in morocco. Paper presented at the 2013 8th 
International Conference on Intelligent Systems: Theories and Applications, SITA, doi:10.1109/SITA.2013.6560791 (2013)

Berrado, A., Elfahli, S., \& El Garah, W. (2013). Using data mining techniques to investigate the factors influencing mobile payment adoption in morocco. Paper presented at the 2013 8th International Conference on Intelligent Systems: Theories and Applications,

Chandrasekhar, U., \& Nandagopal, R. (2016). Mobile Payment Usage Intent in an Indian Context: An Exploratory Study. Asian Journal of Information Technology, 15(3), 542552.

Chandrasekhar, U., Nandagopal, R.: Mobile Payment Usage Intent in an Indian Context: An Exploratory Study. Asian Journal of Information Technology, 15(3), 542--552 (2016)

Cocosila, M., \& Trabelsi, H. (2016). An integrated value-risk investigation of contactless mobile payments adoption. Electronic Commerce Research and Applications, 20, 159170.

Dahlberg, T., Oorni, A.: Understanding changes in consumer payment habits-do mobile payments and electronic invoices attract consumers? 40th Annual Hawaii International Conference on System Sciences (2007)

De Kerviler, G., Demoulin, N. T., \& Zidda, P. (2016). Adoption of in-store mobile payment: Are perceived risk and convenience the only drivers? Journal of Retailing and Consumer Services, 31, 334-344.

Di Pietro, L., Mugion, R. G., Mattia, G., Renzi, M. F., \& Toni, M. (2015). The integrated model on mobile payment acceptance (IMMPA): an empirical application to public transport. Transportation Research Part C: Emerging Technologies, 56, 463-479.

Dwivedi, Y., Wastell, D., Laumer, S., Henriksen, H., Myers, M., Bunker, D., Elbanna, A., Ravishankar, M., Srivastava, S.: Research on information systems failures and successes: Status update and future directions. Information Systems Frontiers, 17, 143--157 (2014)

Dwivedi, Y.K., Rana, N.P., and Janssen, M., Lal, B., Williams, M.D., Clement, M.: An Empirical Validation of a Unified Model of Electronic Government Adoption (UMEGA). Government Information Quarterly, DOI: 10.1016/j.giq.2017.03.001, (2017b)

Dwivedi, Y.K., Rana, N.P., Jeyaraj, A., Clement, M., Williams, M.D. Re-examining the Unified Theory of Acceptance and Use of Technology (UTAUT): Towards a Revised Theoretical Model. Information Systems Frontiers, DOI: 10.1007/s10796-017-9774-y, (2017a)

Eze, U. C., Gan, G. G. G., Ademu, J., \& Tella, S. A. (2008). Modelling user trust and mobile payment adoption: a conceptual Framework. Communications of the IBIMA, 3(29), 224231.

Gao, L., \& Waechter, K. A. (2017). Examining the role of initial trust in user adoption of mobile payment services: an empirical investigation. Information Systems Frontiers, 19(3), 525-548.

Gao, L., Waechter, K.: Examining the role of initial trust in user adoption of mobile payment services: an empirical investigation. Information Systems Frontiers. 19, 525--548, (2015)

Gong, X., Zhang, K. Z., Zhao, S. J., \& Lee, M. K. (2016, June). The effects of Cognitive and Emotional Trust on Mobile Payment Adoption: a Trust Transfer Perspective. In PACIS (p. $350)$.

Gong, X., Zhang, K. Z., Zhao, S. J., Lee, M. K.: The Effects of Cognitive and Emotional Trust on Mobile Payment Adoption: A Trust Transfer Perspective. In Proceedings of Pacific Asia Conference on Information Systems (PACIS), Taiwan (2016)

Guillén, A., Herrera, L., Pomares, H., Rojas, I., Liébana-Cabanillas, F.: Decision Support System to Determine Intention to Use Mobile Payment Systems on Social Networks: A Methodological Analysis. International Journal of Intelligent Systems. 31, 153--172, (2015) 
Hongxia, P., Xianhao, X., \& Weidan, L. (2011, May). Drivers and barriers in the acceptance of mobile payment in China. In E-Business and E-Government (ICEE), 2011 International Conference on (pp. 1-4). IEEE.

Hossain, R., \& Mahmud, I. (2016, January). Influence of cognitive style on mobile payment system adoption: An extended technology acceptance model. In Computer Communication and Informatics (ICCCI), 2016 International Conference on (pp. 1-6). IEEE.

Hossain, R., Mahmud, I.: Influence of cognitive style on mobile payment system adoption: An extended technology acceptance model. Paper presented at the 2016 International Conference on Computer Communication and Informatics, ICCCI, doi:10.1109/ICCCI.2016.7479973 (2016)

Huang, Y., \& Liu, W. (2012, October). The impact of privacy concern on users' usage intention of mobile payment. In Information Management, Innovation Management and Industrial Engineering (ICIII), 2012 International Conference on (Vol. 3, pp. 90-93). IEEE.

Hughes, D., Dwivedi, Y., Rana, N., Simintiras, A.: Information systems project failure analysis of causal links using interpretive structural modelling. Production Planning \& Control, 27, 1313--1333 (2016)

Hughes, D., Dwivedi, Y., Simintiras, A., Rana, N.: Success and failure of IS/IT projects. Springer, Cham, Switzerland (2016)

Jack, W., Suri, T.: Mobile money: The economics of M-PESA (No. w16721). National Bureau of Economic Research (2011)

Jia, L., Hall, D., \& Sun, S. (2014). The effect of technology usage habits on consumers' intention to continue use mobile payments.

Jia, L., Hall, D., \& Zhu, S. (2015). Trust building in consumer learning process and its effect on consumers' behavioral intention toward mobile payments.

Keramati, A., Taeb, R., Larijani, A., Mojir, N.: A combinative model of behavioural and technical factors affecting 'Mobile'-payment services adoption: an empirical study. The Service Industries Journal, 32, 1489--1504 (2012)

Kapoor, K., Dwivedi, Y., Williams, M.: Examining the role of three sets of innovation attributes for determining adoption of the interbank mobile payment service. Information Systems Frontiers, 17, 1039--1056 (2014)

Keramati, A., Taeb, R., Larijani, A., Mojir, N.: A combinative model of behavioural and technical factors affecting 'Mobile'-payment services adoption: an empirical study. The Service Industries Journal, 32, 1489--1504 (2012)

Kim, C., Mirusmonov, M., \& Lee, I. (2010). An empirical examination of factors influencing the intention to use mobile payment. Computers in Human Behavior, 26(3), 310-322.

Kim, Y., Park, Y. J., \& Choi, J. (2016). The Adoption of Mobile Payment Services for "Fintech". International Journal of Applied Engineering Research, 11(2), 1058-1061.

Kim, Y., Park, Y. J., Choi, J.: The Adoption of Mobile Payment Services for "Fintech". International Journal of Applied Engineering Research, 11(2), 1058--1061(2016)

Koenig-Lewis, N., Marquet, M., Palmer, A., Zhao, A.: Enjoyment and social influence: predicting mobile payment adoption. The Service Industries Journal. 35, 537--554 (2015)

Koenig-Lewis, N., Marquet, M., Palmer, A., \& Zhao, A. L. (2015). Enjoyment and social influence: predicting mobile payment adoption. The Service Industries Journal, 35(10), 537-554.

Komiak, S. Y., Benbasat, I.: The effects of personalization and familiarity on trust and adoption of recommendation agents. MIS quarterly 30(4), 941--960 (2006)

Lee, J. B., Lee, S. B., \& Park, C. (2015). A Study on the Individual and Environmental Factors Affecting Mobile Payment Service Acceptance-A Focus on NFC-based 
Payment ServicesJae-Beom. International Information Institute (Tokyo). Information, 18(4), 1185.

Lee, J. B., Lee, S. B., Park, C.: A Study on the Individual and Environmental Factors Affecting Mobile Payment Service Acceptance-A Focus on NFC-based Payment ServicesJae-Beom. International Information Institute (Tokyo). Information, 18(4), 1185 (2015)

Li, H., Liu, Y., \& Heikkilä, J. (2014). Understanding the Factors Driving NFC-Enabled Mobile Payment Adoption: an Empirical Investigation. In PACIS (p. 231).

Liébana-Cabanillas, F., Muñoz-Leiva, F., \& Sánchez-Fernández, J. (2015a). Influence of age in the adoption of new mobile payment systems. Revista Brasileira de Gestão de Negócios, 17(58).

Liébana-Cabanillas, F., Muñoz-Leiva, F., Sánchez-Fernández, J.: Influence of age in the adoption of new mobile payment systems. Revista Brasileira de Gestão de Negócios, 17(58), 1390 (2015)

Liébana-Cabanillas, F., Ramos de Luna, I., \& Montoro-Ríos, F. J. (2015). User behaviour in QR mobile payment system: the QR Payment Acceptance Model. Technology Analysis \& Strategic Management, 27(9), 1031-1049.

Liébana-Cabanillas, F., Sánchez-Fernández, J., Muñoz-Leiva, F.: Antecedents of the adoption of the new mobile payment systems: The moderating effect of age. Computers in Human Behavior. 35, 464--478 (2014)

Liébana-Cabanillas, F., Sánchez-Fernández, J., Muñoz-Leiva, F.: The moderating effect of experience in the adoption of mobile payment tools in Virtual Social Networks: The mPayment Acceptance Model in Virtual Social Networks (MPAM-VSN). International Journal of Information Management. 34, 151--166, (2014)

Liu, B. (2012, October). Understanding Consumers' Intention to Use Mobile Payment Services: The Perspective of University Students in Northern Jiangsu Area. In Proceedings of Second International Conference on Business Computing and Global Informatization (BCGIN), 2012 (pp. 257-260). IEEE.

Lu, J., Wei, J., Yu, C. S., \& Liu, C. (2017). How do post-usage factors and espoused cultural values impact mobile payment continuation?. Behaviour \& Information Technology, 36(2), 140-164.

Lu, Y., Yang, S., Chau, P. Y., \& Cao, Y. (2011). Dynamics between the trust transfer process and intention to use mobile payment services: A cross-environment perspective. Information \& Management, 48(8), 393-403.

Makki, A. M., Ozturk, A. B., \& Singh, D. (2016). Role of risk, self-efficacy, and innovativeness on behavioral intentions for mobile payment systems in the restaurant industry. Journal of Foodservice Business Research, 19(5), 454-473.

Mallat, N. (2007). Exploring consumer adoption of mobile payments-A qualitative study. The Journal of Strategic Information Systems, 16(4), 413-432.

Mallat, N.: Exploring consumer adoption of mobile payments - A qualitative study. The Journal of Strategic Information Systems. 16, 413--432 (2007)

Mingxing, S., Jing, F., \& Yafang, L. (2014, October). An empirical study on consumer acceptance of mobile payment based on the perceived risk and trust. In proceedings of International Conference on Cyber-Enabled Distributed Computing and Knowledge Discovery (CyberC), 2014 (pp. 312-317).

Mobile financial services development report: http://www3.weforum.org/docs/ WEF_MFSD_Report_2011.pdf, (2011).

Moore, G. C., Benbasat, I. (1991). Development of an instrument to measure the perceptions of adopting an information technology innovation. Information Systems Research, 2(3), 192-222. 
Morosan, C., \& DeFranco, A. (2016). It's about time: Revisiting UTAUT2 to examine consumers' intentions to use NFC mobile payments in hotels. International Journal of Hospitality Management, 53, 17-29.

Musa, A., Khan, H. U., \& AlShare, K. A. (2015). Factors influence consumers' adoption of mobile payment devices in Qatar. International journal of mobile communications, 13(6), 670-689.

Oliveira, T., Thomas, M., Baptista, G., Campos, F.: Mobile payment: Understanding the determinants of customer adoption and intention to recommend the technology. Computers in Human Behavior. 61, 404-414 (2016)

Oliveira, T., Thomas, M., Baptista, G., \& Campos, F. (2016). Mobile payment: Understanding the determinants of customer adoption and intention to recommend the technology. Computers in Human Behavior, 61, 404-414.

Ozturk, A. B., \& Ozturk, A. B. (2016). Customer acceptance of cashless payment systems in the hospitality industry. International Journal of Contemporary Hospitality Management, 28(4), 801-817.

Pal, D., Vanijja, V., \& Papasratorn, B. (2015). An empirical analysis towards the Adoption of NFC Mobile Payment System by the end user. Procedia Computer Science, 69, 13-25.

Patil, P. P., Dwivedi, Y. K., \& Rana, N. P. (2017). Digital Payments Adoption: An Analysis of Literature. In Conference on e-Business, e-Services and e-Society (pp. 61-70). Springer, Cham.

Peng, R., Xiong, L., \& Yang, Z. (2012). Exploring tourist adoption of tourism mobile payment: An empirical analysis. Journal of theoretical and applied electronic commerce research, 7(1), 21-33.

Pham, T., Ho, J.: The effects of product-related, personal-related factors and attractiveness of alternatives on consumer adoption of NFC-based mobile payments. Technology in Society, 43, 159--172 (2015)

PHONTHANUKITITHAWORN, C., Sellitto, C., \& Fong, M. (1970). User intentions to adopt mobile payment services: A study of early adopters in Thailand. The Journal of Internet Banking and Commerce, 20(1), 1-29.

Qasim, H., \& Abu-Shanab, E. (2016). Drivers of mobile payment acceptance: The impact of network externalities. Information Systems Frontiers, 18(5), 1021-1034.

Rana, N.P., Dwivedi, Y.K., Lal, B., Williams, M.D., Clement, M.: Citizens' Adoption of an Electronic Government System: Toward a Unified View. Information Systems Frontiers, 19(3), 549--568 (2017)

Rana, N.P., Dwivedi, Y.K., Williams, M.D., Weerakkody, V.: Adoption of Online Public Grievance Redressal System in India: Toward Developing a Unified View. Computers in Human Behavior, 59, 265--282 (2016)

Sam, K. M., Chatwin, C. R., \& Zhang, J. X. (2014, December). Adoption of near field communication for mobile payment: Evidence from Macau. In Industrial Engineering and Engineering Management (IEEM), 2014 IEEE International Conference on (pp. 1121-1125). IEEE.

Schierz, P. G., Schilke, O., \& Wirtz, B. W. (2010). Understanding consumer acceptance of mobile payment services: An empirical analysis. Electronic commerce research and applications, 9(3), 209-216.

Shin, S., \& Lee, W. J. (2014). The effects of technology readiness and technology acceptance on NFC mobile payment services in Korea. Journal of Applied Business Research, 30(6), 1615.

Sivathanu, B., \& Sivathanu, B. (2018). Adoption of digital payment systems in the era of demonetization in India: An empirical study. Journal of Science and Technology Policy Management. 
Slade, E. L., Dwivedi, Y. K., Piercy, N. C., \& Williams, M. D. (2015b). Modeling consumers' adoption intentions of remote mobile payments in the United Kingdom: extending UTAUT with innovativeness, risk, and trust. Psychology \& Marketing, 32(8), 860-873.

Slade, E., Dwivedi, Y., Piercy, N., Williams, M.: Modeling Consumers' Adoption Intentions of Remote Mobile Payments in the United Kingdom: Extending UTAUT with Innovativeness, Risk, and Trust. Psychology \& Marketing. 32, 860--873 (2015)

Slade, E., Williams, M., Dwivedi, Y., \& Piercy, N. (2015a). Exploring consumer adoption of proximity mobile payments. Journal of Strategic Marketing, 23(3), 209-223.

Slade, E., Williams, M., Dwivedi, Y.: Devising a research model to examine adoption of mobile payments: An extension of UTAUT2. The Marketing Review. 14, 310--335 (2014)

Staykova, K., Damsgaard, J.: Adoption of Mobile Payment Platforms: Managing Reach and Range. Journal of theoretical and applied electronic commerce research. 11, 66--85 (2016)

Thakur, R., Srivastava, M.: Adoption readiness, personal innovativeness, perceived risk and usage intention across customer groups for mobile payment services in India. Internet Research. 24(3), 369--392 (2014)

Tian, Y., \& Dong, H. (2013, September). An analysis of key factors affecting user acceptance of mobile payment. In Informatics and Applications (ICIA), 2013 Second International Conference on (pp. 240-246). IEEE.

Tornatzky, L. G., Klein, K. J.: Innovation characteristics and innovation adoptionimplementation: A meta-analysis of findings. IEEE Transactions on engineering management, 1, 28--45 (1982)

Venkatesh, V., Morris, M. G., Davis, G. B., Davis, F. D.: User acceptance of information technology: Toward a unified view. MIS Quarterly, 27(3), 425--478 (2003)

World Economic Forum (2011). Mobile financial services development report: http://reports.weforum.org/wp-content/pdf/mfsr-2011/wef-mfsd-report-2011.pdf

Wu, J., Liu, L., \& Huang, L. (2016, June). Exploring User Acceptance of Innovative Mobile Payment Service in Emerging Market: The moderating effect of diffusion stages of WeChat Payment in China. In PACIS (p. 238).

Xin, H., Techatassanasoontorn, A. A., \& Tan, F. B. (2013). Exploring the influence of trust on mobile payment adoption.

Xin, H., Techatassanasoontorn, A. A., \& Tan, F. B. (2015). Antecedents of consumer trust in mobile payment adoption. Journal of Computer Information Systems, 55(4), 1-10.

Yan, H., \& Yang, Z. (2014, October). An Empirical Examination of User Adoption Mobile Payment. In Management of e-Commerce and e-Government (ICMeCG), 2014 International Conference on (pp. 156-162). IEEE.

Yang, S., Cao, Y., Mao, W., Zhang, R., \& Luo, L. (2011, November). Determinants of behavioral intention to mobile payment: Evidence from China. In Advanced Information Management and Service (ICIPM), 2011 7th International Conference on (pp. 151-154). IEEE.

Yang, S., Lu, Y., Gupta, S., Cao, Y., \& Zhang, R. (2012). Mobile payment services adoption across time: An empirical study of the effects of behavioral beliefs, social influences, and personal traits. Computers in Human Behavior, 28(1), 129-142.

Yang, Y., Liu, Y., Li, H., \& Yu, B. (2015). Understanding perceived risks in mobile payment acceptance. Industrial Management \& Data Systems, 115(2), 253-269.

Zhang, A., Yue, X., \& Kong, Y. (2011, June). Exploring culture factors affecting the adoption of mobile payment. In Mobile Business (ICMB), 2011 Tenth International Conference on (pp. 263-267). IEEE.

Zhanga, A., Yue, X., Kong, Y.: Exploring culture factors affecting the adoption of mobile payment. Tenth International Conference on Mobile Business, 263--267 (2011) 
Zhong, J., Dhir, A., Nieminen, M., Hämäläinen, M., Laine, J.: Exploring consumer adoption of mobile payments in china. Paper presented at the Proceedings of the 17th International Academic MindTrek Conference: "Making Sense of Converging Media", MindTrek, 318--325 (2013)

Zhong, J., Dhir, A., Nieminen, M., Hämäläinen, M., \& Laine, J. (2013, October). Exploring consumer adoption of mobile payments in China. In Proceedings of International Conference on Making Sense of Converging Media (p. 318). ACM.

Zhou, T. (2011). The effect of initial trust on user adoption of mobile payment. Information Development, 27(4), 290-300.

Zhou, T. (2013). An empirical examination of continuance intention of mobile payment services. Decision Support Systems, 54(2), 1085-1091.

Zhou, T. (2014). Understanding the determinants of mobile payment continuance usage. Industrial Management \& Data Systems, 114(6), 936-948. 